\title{
NON TIMBER FOREST PRODUCT UTILIZATIONS AND AWARENESS OF SMALL-SCALE INDUSTRY DEVELOPMENT IN FOREST COMMUNITIES- A CASE STUDY IN EAST KALIMANTAN
}

\author{
Eli Nur Nirmala Sari ${ }^{1}$
}

\begin{abstract}
A lack of livelihood to meet the needs has been one reason why forest communities have utilized non-timber forest products (NTFPs). For some communities living in or around forest areas, NTFPs have been a basic support for their small-scale industries, which could contribute to better income. This study focused on the utilization of NTFPs by forest communities and their awareness in terms of utilizing such products for handicrafts in small-scale industry. This study examined the NTFPs potentials, markets, and social benefits at the five villages in East Kalimantan, Indonesia. The villages-surveyed were Batu Lidung, Punan Bengalun, Sesua, Mendupo, and Seputuk which were located in and near forest areas managed by PT Intracawood Manufacturing as a forest concessionaire. The method used was Participatory Rural Appraisal Techniques, and the data collection was based on primary data and household survey. The result suggested that among the five villages, the most remote area was Punan Bengalun. Forest community of Punan Bengalun has started selling the handicrafts made from NTFPs only in the last few years. Among the five villages-surveyed, the forest community in Seputuk tended to be more active in utilizing NTFPs for small-scale industry rather than those in four other villages. Awareness in utilizing the NTFPs had been mostly depended on factor of forest distance from the villages. People living close to the district capital (where there was a wider variety of employment opportunities) had less motivation to utilize NTFPs although there were available.
\end{abstract}

Keywords: natural forest, non timber forest products, utilization, awareness

\section{INTRODUCTION}

Forests contribute significantly in fulfilling the needs of forest communities (Ali et al., 2007). Evidence from the field indicates that forests and forest communities exist in a state of symbiosis. Forests supply food, income, medicine, and nutrition through the materials they produce, and provide shelter (Pierce, 1999), recreation, and safety for forest communities.

One of the benefits of forests is the availability of natural resources to fulfill the community needs. Since the introduction of forest concessionaire activities in the $1970 \mathrm{~s}$ in Indonesia, the communities have been prohibited from utilizing timber. However,

\footnotetext{
${ }^{1}$ Graduate School of Environmental Science, Hokkaido University, Japan

Email: elinns@exfor.agr.hokudai.ac.jp; eli_nns@hotmail.com
} 
there is still plenty of NTFP utilization in communities - such products are an important part of their livelihoods (Pierce, 1999). Although many researchers argue that NTFPs are important for forest communities, the role of these products economically has not yet been identified. NTFPs in Indonesia have already been exploited and harvested by forest communities for daily life (Malik and Sumadiwangsa, 2003), but most people living in or around the forests in Indonesia are still considered poor. The significance of NTFP' role in forest community economic in Indonesia is not yet known. People who gather NTFPs usually live in remote areas, and are poor with low formal education (FAO, 2008). They are forced to fulfill their daily needs from forests, and run their business by selling the NTFPs, such as fruits and handicrafts made of NTFPs. Forest communities have started these activities for many years since recognizing currency as payment for goods and services.

Although it is well known that forests have tremendous potential in providing NTFPs, some forest communities remain relatively unaware of the economic potential. Many of them do not have any motivation to utilize the natural resources to increase their economic status, even though it is known that forest products - especially NTFPs - can be utilized to make handicrafts and offer opportunities for small-scale industry. In relation to these opportunities, the impact of product substitution and the possibility of creating new markets need to be examined, together with the impact of changes in collection, processing, and marketing patterns. As Tewari and Campbell (1995) mentioned that price, supply, and demand trends will need to be assessed to determine medium- and long-term economic viability and the market's absorptive capacity for each type of NTFP. Forest communities have their own capacity to earn income from the NTFP sector. However, many factors weaken their desire to build awareness of these opportunities.

This study examined the NTFPs potentials, markets, and social benefits at the five villages in East Kalimantan. Komarudin et al. (2007) mentioned that NTFPs could potentially provide more value over the long term. In terms of the extent to which forest communities use NTFPs and their awareness of NTFPs utilization to increase income, this study analyzed the relationships between community forest-related activities and factors affecting forest dependency to assess whether residents are aware of the potential of forests and the opportunities to develop small-scale industry. The three goals of this study were: (1) to identify factors that affect NTFP utilization by forest communities; (2) to identify small-scale industry related to NTFPs utilization; and (3) to identify the conditions of business/industry activities and ascertain direction of forest community development. 


\section{METHODS}

\section{A. Study Site}

This study was undertaken in two sub-districts of East Kalimantan Province: Sesayap, which is located in Bulungan District, and Malinau, which is located in Malinau District (Figure 1). Within these two sub-districts, three villages in Malinau (Batu Lidung, Punan Bengalun, and Sesua) and two villages in Sesayap (Mendupo and Seputuk) were pointed (Table 1). All five villages are located in or near forest areas of PT. Intracawood Manufacturing ${ }^{2}$. The five villages were selected because of the effective nature of collection among the particular communities; and this appeared to influence activities related to their forest dependence. Large rivers also pass through each of these villages, which was probably one of the reasons why the communities settled there. Most of the communities in these five villages were farmers and using rivers for drinking, washing, and bathing.

Before the political changes in 1998, the old district of Bulungan consisted of three areas that are now becoming different districts (Palmer, 2004). The Malinau District was established in 1999, and covers an area of 4,262,000 ha consisting of $98 \%$ forest, and the other $2 \%$ is classified as areas for agriculture, mining, and other uses (Suwarno and Campbell, 2005). The forests in Malinau District are classified as production forests, conservation forests, and protection forests. They are considered to represent one of the fifteen tropical rain forest hotspots in the world (Mittermeier and Bowles, 1993).

Bulungan District is in the northern part of East Kalimantan Province, and covers an area of $1,801,050$ ha. There are many small islands in the area within numerous large and small rivers. Job opportunities in the district are categorized into nine different sectors, i.e. agriculture, mining, industry, construction, trade, transportation, communications, finance, and services. The first and second largest sectors are agriculture and trade, with shares of 68.8 and $9.5 \%$, respectively, and the minority is the service sector, with a share of only $0.7 \%$ (BPS, 2006). The forests cover an area of $1,386,356$ ha, which includes conservation, production, and limited production forests. Forest management

\footnotetext{
${ }^{2}$ PT. Intracawood Manufacturing is an HPH (Hak Pengusahaan Hutan = forest concession holder) that has operated since 1988 on behalf of state-owned company - PT. Inhutani I (the main HPH since 1976). PT. Intracawood Manufacturing managed 250,000 hectares of forest at the beginning of its management, and reduced to 195,000 hectares by August 2003. In 2006, 38 villages were located in and around the forest area. After establishment of the concession holders in this area in the 1970s, communities living in or near the forest faced restrictions on the utilization of forest products as declared in a policy introduced by the HPH. These communities are no longer free to utilize forest products. This directly or indirectly affects their incomes. Since 1997, the Indonesian Ministry of Forestry obligated that all concession holders in Indonesia had to offer support and development to local communities. To date, PT. Intracawood Manufacturing has supported local communities by providing funds to develop infrastructure and assist local community needs related to education, health, religion, culture and safety. The establishment of HPHs brings advantages and disadvantages to such communities.
} 
is implemented by forest concession companies, and in 2005 three forest concessionaires were activated to manage 457,585 ha of forests in Bulungan District (BPS, 2006).
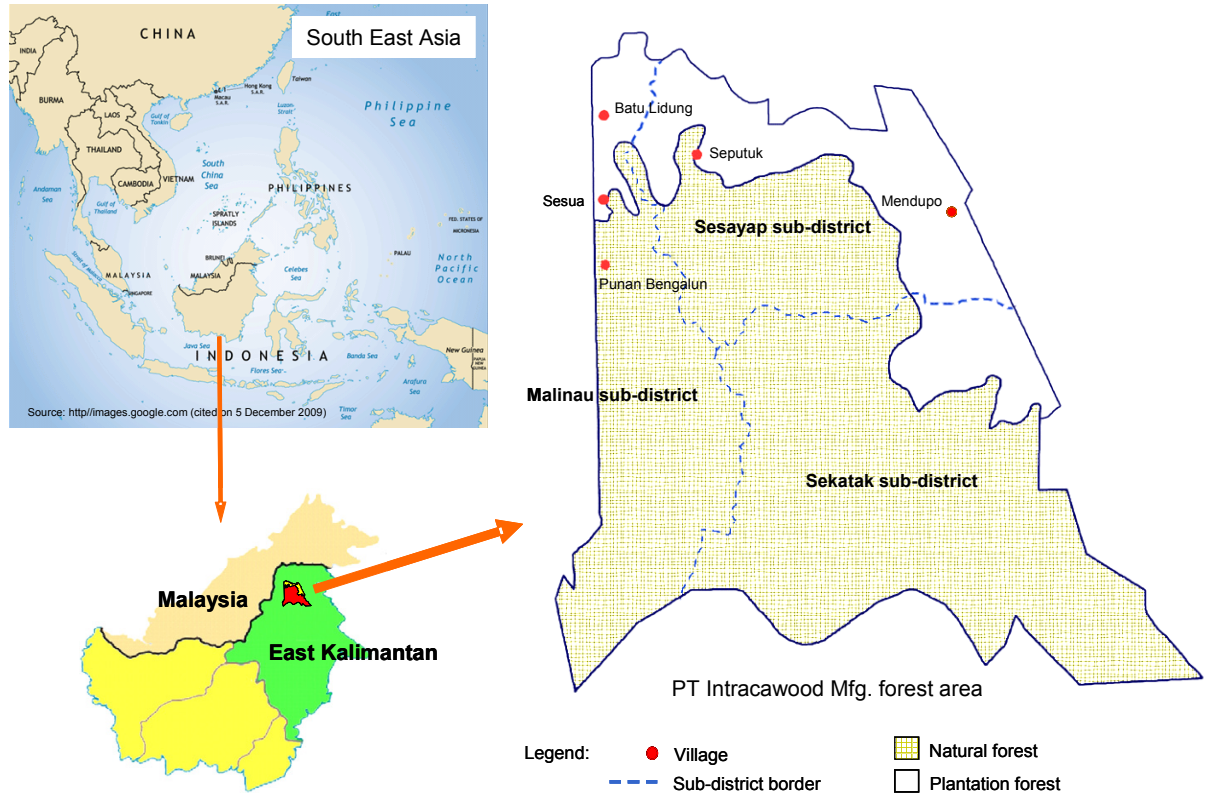

Source: PT Intracawood Mfg. 2007

Figure 1. Research site

Table 1. Information of five villages surveyed

\begin{tabular}{|c|c|c|c|c|c|c|c|c|c|c|}
\hline \multirow[t]{2}{*}{ Village } & \multirow[t]{2}{*}{ District } & \multicolumn{2}{|c|}{$\begin{array}{l}\text { Number of } \\
\text { households }\end{array}$} & \multicolumn{2}{|c|}{$\begin{array}{l}\text { Number of house- } \\
\text { holds utilizing } \\
\text { NTFPs (\%) }\end{array}$} & \multicolumn{2}{|c|}{$\begin{array}{l}\text { Number of } \\
\text { households } \\
\text { utilizing NTFPs } \\
\text { to make handi- } \\
\text { crafts for sale to } \\
\text { others/markets } \\
(\%)\end{array}$} & \multirow[t]{2}{*}{$\begin{array}{l}\text { Year of village } \\
\text { establishment }\end{array}$} & \multicolumn{2}{|c|}{$\begin{array}{l}\text { Distance from village } \\
\text { center to: } \\
(\mathrm{km})\end{array}$} \\
\hline & & 1996 & 2006 & 1996 & 2006 & 1996 & 2006 & & $\begin{array}{l}\text { Sub-district } \\
\text { market }\end{array}$ & $\begin{array}{l}\text { Major con- } \\
\text { sumption } \\
\text { goods market }\end{array}$ \\
\hline $\begin{array}{l}\text { Batu } \\
\text { Lidung }\end{array}$ & Malinau & 90 & 213 & 60 & 18 & 12 & 4 & 1958 & 3 & 3 \\
\hline $\begin{array}{l}\text { Punan } \\
\text { Bengalun }\end{array}$ & Malinau & 43 & 45 & 100 & 100 & 0 & 55 & 1975 & 35 & 35 \\
\hline Sesua & Malinau & 120 & 195 & 70 & 42 & 41 & 12 & 1948 & 22 & 0 \\
\hline Mendupo & Bulungan & 65 & 70 & 100 & 95 & 46 & 42 & 1950 & 35 & 27 \\
\hline Seputuk & Bulungan & 50 & 100 & 100 & 100 & 60 & 40 & 1945 & 45 & 25 \\
\hline
\end{tabular}

Note: The data were collected from interviews with the chiefs of the five villages surveyed. 


\section{B. Data Collection and Analysis}

The study was based mainly on primary data, and the other information was collected through a household survey. The investigation was carried out in March 2008. A stratified sample of households was chosen by performing a census of village dwellings using Participatory Rural Appraisal Techniques. A questionnaire interview was implemented with 65 households ( 13 households for each village) who were active in utilizing NTFPs and making handicrafts. The samples consisted of $23 \%$ male and $77 \%$ female. There were more female because they were more active in utilizing NTFPs and making handicrafts. All the household members surveyed were natives. Pre-testing questionnaires were given to respondents in the sample villages to test questionnaire effectiveness. Some questions that were not relevant to the communities' context in the villages were removed, and other new questions were added. To minimize bias, every completed questionnaire was signed whether it was complete or not. Incomplete questionnaires were not included in the data analysis. Descriptive analysis was used to present data of household perceptions toward NTFP utilization and small-scale industry opportunities.

To achieve the goals of the study, data on the following points were collected: (1) factors that influence forest community awareness toward NTFP utilization; (2) factors that influence forest communities to not utilize NTFPs; (3) obstacles faced by forest communities in utilizing NTFPs; and (4) possible ways to increase forest community living standards through small-scale industry.

\section{RESULTS AND DISCUSSION}

\section{A. Potential of NTFPs and their Utilization by Forest Communities}

After the establishment of the forest concessionaire, the villagers were still allowed to utilize the NTFPs, such as rattan (used as a tying material in hut or house construction), medicinal plants, ginseng, latex from poisonous wood used for sumpit (blow gun) traditional weapons, honey, leaves for rice wrapping, fruits, and animals. In general, they still utilize the forest as a source of life. However, they have less opportunity to utilize the timbers in line with regulations introduced by the Indonesian Ministry of Forestry. This condition has reduced forest community incomes. The same theory was mentioned by Yasmi (2003), that the dependency of communities on forest has now decreased in response to a number of factors, including restrictions on the utilization of forest products by forest managers.

The five villages surveyed - Batu Lidung, Punan Bengalun, Sesua, Mendupo, and Seputuk - were established in their current locations in 1958, 1975, 1948, 1950, and 1945 , respectively (Table 1 ). Before settlement, there was an abundant supply of forest products. However, they reported that the availability of these materials after settlement was lower than that in their previous locations. Moreover, since forest concessionaires 
became active in forest management in the 1970s, their over harvesting of timber has reduced the availability of NTFPs (FAO, 1997). In the five villages-surveyed, residents reported that they had more difficulty to find sources of NTFPs since the establishment of forest concessionaires. Previously, before the establishment of forest concessionaires, forest communities could easily find animals for food, gaharu to be sold, fruits, honey, fish from rivers, and other NTFPs from various sources to meet their needs. In general, communities living in or near forest areas depend on them for life, especially for food where it is lacking (Quang and Anh, 2006). However, since the establishment of forest concessionaire, communities had gradually experienced higher levels of difficulty in finding resources - especially gaharu ${ }^{3}$, animals, and fishes - because of the deterioration of environmental quality. Logging by forest concessionaires had killed off many gaharu trees, dispersed animal and bee populations, and caused a deterioration of water quality in rivers passing through forest community settlements. This drop in water quality has in turn caused a reduction in fish populations.

In the villages-surveyed, the majority of NTFPs for handicrafts that forest communities used were rattan (Calamus spp.), bamboo (Bambusoideae), pandan (Pandanus spp.), and silat leaves (Palmae). These NTFPs were used to make handicrafts such as anjat and bakul (woven basket), mat, winnowing basket, kedabang (head covering), and bubu (fish trap). Not all of the forest communities in the villages could produce handicrafts - it is an ability passed down from previous generations. Usually, villagers who were unable to make such items will order them from other villagers, so those with the necessary skills could also sell them besides using them to fulfill their own needs. This demonstrated how handicraft making represents a source of income. The availability, access, and use of NTFPs in the five villages-surveyed are shown in Table 2. In most of the villages, it was found that the availability of NTFPs was high in 1990 and decreased in 2008. In some villages, although the availability of NTFPs in forests was decreasing and access to find them had become difficult, villagers still fulfilled their needs independently by planting NTFPs on their own agricultural land or in their home gardens. In Seputuk Village, most residents planted rattan, bamboo, and pandan to support their material needs for making handicrafts. The sources of handicraft materials and the utilization of the products manufactured are shown in Table 3. Meanwhile, Table 4 listed the activities of handicraft making by the 65 households interviewed, and shows the purpose of production. However, some communities sold their products to other villagers and to the market. Some were also found to buy products from other villagers even though they were capable of making them by themselves. The ownership of money by some communities was one of the reasons why they prefered to buy those products rather than produced them by themselves.

\footnotetext{
${ }^{3}$ Gaharu is a fragrant resin created from fungal infection of Aquilaria spp., commonly known as gaharu trees (Limberg et al., 2005). Gaharu collectors sell the resin to buyers or traders, who then export it to Middle Eastern countries. As gaharu has now decreased (Levang et al., 2005), the number of gaharu collectors has decreased.
} 
Table 2. NTFP utilization by forest communities (results of interview from 65 households in the five villages surveyed)

\begin{tabular}{|c|c|c|c|c|c|c|c|c|c|c|}
\hline \multirow{2}{*}{ No. } & \multirow{2}{*}{\multicolumn{2}{|c|}{ Village surveyed }} & \multicolumn{2}{|c|}{ Rattan } & \multicolumn{2}{|c|}{ Bamboo } & \multicolumn{2}{|c|}{ Silat leaves } & \multicolumn{2}{|c|}{ Pandan } \\
\hline & & & 1990 & 2008 & 1990 & 2008 & 1990 & 2008 & 1990 & 2008 \\
\hline \multirow[t]{3}{*}{1} & Batu Lidung & Availability & + & $\mathrm{x}$ & + & $\mathrm{x}$ & + & $\mathrm{x}$ & + & $\mathrm{x}$ \\
\hline & & Access & + & $\mathrm{x}$ & + & $\mathrm{x}$ & $\mathrm{x}$ & $\mathrm{x}$ & + & $\mathrm{x}$ \\
\hline & & Use & $\mathrm{x}$ & - & $\mathrm{x}$ & - & - & - & $\mathrm{x}$ & - \\
\hline \multirow[t]{3}{*}{2} & $\begin{array}{l}\text { Punan } \\
\text { Bengalun }\end{array}$ & Availability & + & + & + & + & + & + & + & + \\
\hline & & Access & + & + & + & + & + & + & + & + \\
\hline & & Use & + & + & $\mathrm{x}$ & $\mathrm{x}$ & + & + & + & + \\
\hline \multirow[t]{3}{*}{3} & Sesua & Availability & + & $\mathrm{x}$ & $\mathrm{x}$ & $\mathrm{x}$ & $\mathrm{x}$ & $\mathrm{x}$ & + & $\mathrm{x}$ \\
\hline & & Access & $\mathrm{x}$ & $\mathrm{x}$ & $\mathrm{x}$ & - & $\mathrm{x}$ & $\mathrm{x}$ & $\mathrm{x}$ & $\mathrm{x}$ \\
\hline & & Use & $\mathrm{x}$ & - & - & - & - & - & $\mathrm{x}$ & $\mathrm{x}$ \\
\hline \multirow[t]{3}{*}{4} & Mendupo & Availability & + & + & + & + & + & + & + & + \\
\hline & & Access & + & + & + & + & + & + & + & + \\
\hline & & Use & + & + & + & + & $\mathrm{x}$ & $\mathrm{x}$ & + & + \\
\hline \multirow[t]{3}{*}{5} & Seputuk & Availability & + & + & + & + & + & + & + & + \\
\hline & & Access & + & $\mathrm{x}$ & + & $\mathrm{x}$ & + & + & + & $\mathrm{x}$ \\
\hline & & Use & + & + & + & + & + & + & + & + \\
\hline
\end{tabular}

Availability: "+" = plentiful, "x" = sufficient, "-" = less

Access: "+" = easy, "x" = medium, "-" = difficult

Use: "+" = plentiful, "x" = sufficient, "-" = less 
Table 3. Handicraft making from NTFPs by forest communities in the five villages surveyed $(n=65)$ : production by gender and material sources

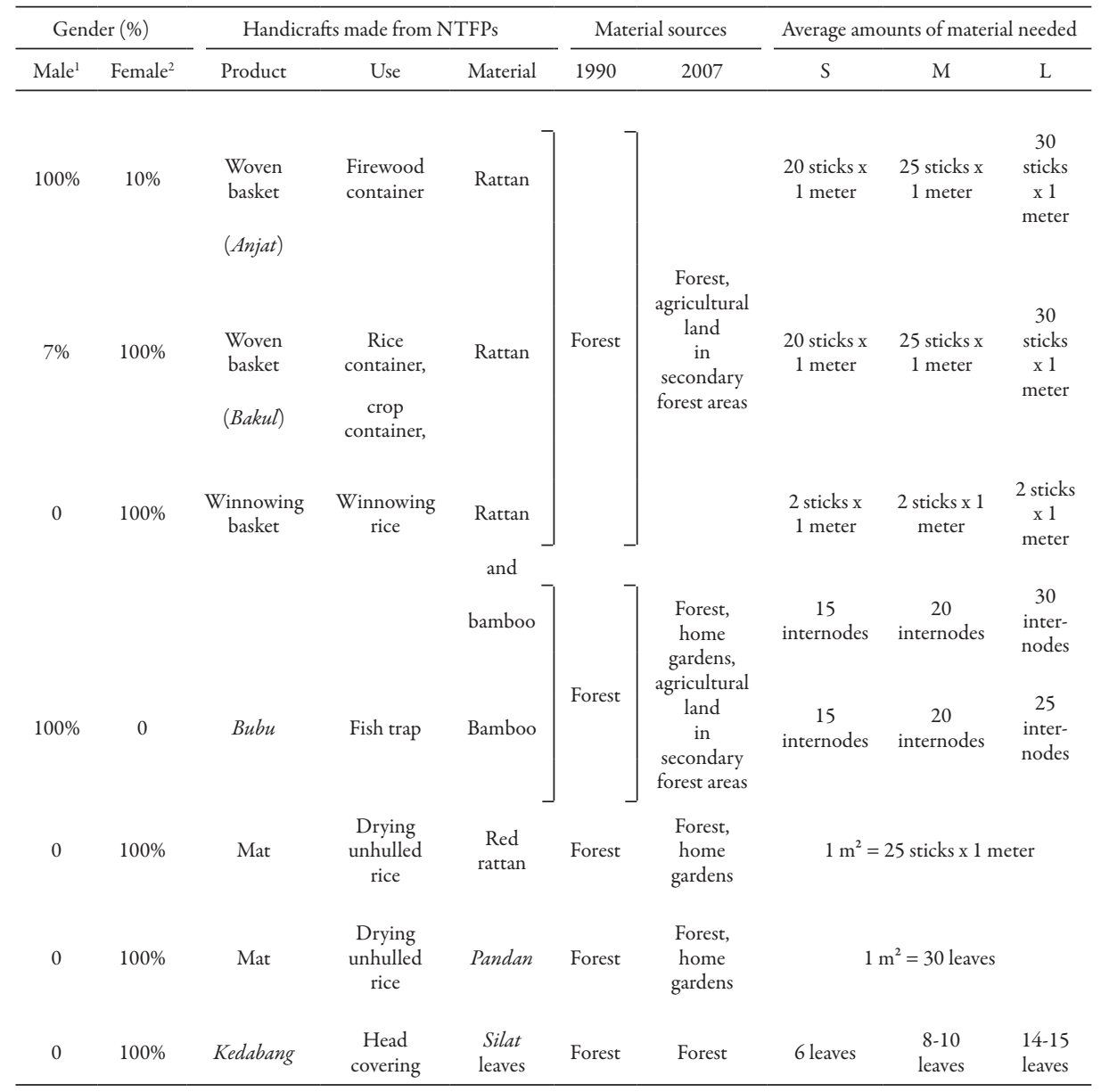

1) $(\mathrm{n}=15) ;{ }^{2)}(\mathrm{n}=50)$;

$S=$ Small, $M=$ Medium, $L=$ Large 
Table 4. Results of interview from 65 households in the five villages surveyed: activities related to handicraft making

\begin{tabular}{|c|c|c|c|c|c|c|c|c|c|c|}
\hline \multirow{2}{*}{ Village } & \multirow{2}{*}{$\begin{array}{l}\text { Number of } \\
\text { households }\end{array}$} & \multirow{2}{*}{$\begin{array}{l}\text { Average } \\
\text { age }\end{array}$} & \multirow{2}{*}{$\begin{array}{l}\text { Main } \\
\text { liveli- } \\
\text { hood }\end{array}$} & \multirow{2}{*}{ Name of product } & \multirow{2}{*}{$\begin{array}{l}\text { Average } \\
\text { time to } \\
\text { finish one } \\
\text { unit (per } \\
\text { person) }\end{array}$} & \multicolumn{3}{|c|}{$\begin{array}{l}\text { Unit price (IDR) in } 2007 \\
\qquad(x 1000)\end{array}$} & \multicolumn{2}{|c|}{$\begin{array}{l}\text { Purpose of } \\
\text { production }\end{array}$} \\
\hline & & & & & & $S$ & M & $\mathrm{L}$ & 1990 & 2007 \\
\hline \multirow{7}{*}{ 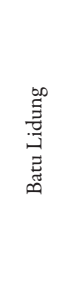 } & \multirow{7}{*}{$\begin{array}{c}13 \\
(\text { Male }=3 \\
\text { Female }= \\
10)\end{array}$} & \multirow[t]{7}{*}{53} & \multirow{7}{*}{ 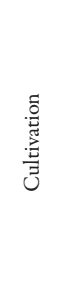 } & Woven basket (Anjat) & 7 days & 25 & 30 & 50 & \multirow{7}{*}{$\begin{array}{l}\text { Own } \\
\text { use }\end{array}$} & \multirow{7}{*}{$\begin{array}{c}\text { Own use, } \\
\text { sale to } \\
\text { other } \\
\text { villagers }\end{array}$} \\
\hline & & & & Woven basket (Bakul) & 5-6 days & 60 & 70 & 100 & & \\
\hline & & & & Winnowing basket & 1 day & 15 & 20 & 25 & & \\
\hline & & & & Bubu & 1 day & 15 & $20-30$ & 50 & & \\
\hline & & & & Red rattan mat & 7 days & \multicolumn{3}{|c|}{$1.5 \times 4 \mathrm{~m}=500$} & & \\
\hline & & & & Pandanus mat & 7 days & \multicolumn{3}{|c|}{$1 \times 1.8 \mathrm{~m}=100$} & & \\
\hline & & & & Kedabang & 1 day & 15 & 20 & $25-30$ & & \\
\hline \multirow{7}{*}{ 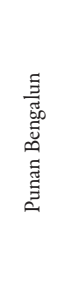 } & \multirow{7}{*}{$\begin{array}{c}13 \\
(\text { Male = 3; } \\
\text { Female } \\
=10)\end{array}$} & \multirow[t]{7}{*}{43.7} & \multirow{7}{*}{ 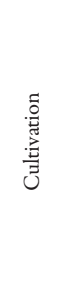 } & Woven basket (Anjat) & 7 days & 20 & - & 30 & \multirow{7}{*}{$\begin{array}{l}\text { Own } \\
\text { use }\end{array}$} & \multirow{7}{*}{$\begin{array}{c}\text { Own use, } \\
\text { sale to } \\
\text { other } \\
\text { villagers }\end{array}$} \\
\hline & & & & Woven basket (Bakul) & 3-4 days & 15 & 20 & 50 & & \\
\hline & & & & Winnowing basket & 3 days & 15 & 20 & 20 & & \\
\hline & & & & Bubu & 2 days & - & - & - & & \\
\hline & & & & Red rattan mat & 10 days & \multicolumn{3}{|c|}{$1.5 \times 4 \mathrm{~m}=200$} & & \\
\hline & & & & Pandanus mat & $7-10$ days & \multicolumn{3}{|c|}{$1 \times 1.8 \mathrm{~m}=100$} & & \\
\hline & & & & Kedabang & 2 days & 15 & 20 & 30 & & \\
\hline \multirow{7}{*}{ 苐 } & 13 & 40.3 & & Woven basket (Anjat) & 7 days & 30 & 45 & 75 & & \\
\hline & $($ Male $=3$ & & & Woven basket (Bakul) & 6-7 days & 25 & 30 & 50 & & \\
\hline & $\begin{array}{c}\text { Female }= \\
10)\end{array}$ & & $\Xi$ & Winnowing basket & 1 day & 20 & - & 25 & & \\
\hline & & & 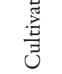 & $B u b u$ & $2-3$ days & 20 & - & 30 & $\begin{array}{c}\text { Own } \\
\text { use }\end{array}$ & $\begin{array}{c}\text { sale to } \\
\text { other } \\
\text { villagers }\end{array}$ \\
\hline & & & & Red rattan mat & 7 days & & $\mathrm{x} 4 \mathrm{~m}=$ & & & \\
\hline & & & & Pandanus mat & 6-7 days & & $1.8 \mathrm{~m}=$ & & & \\
\hline & & & & Kedabang & 1 day & 20 & - & 25 & & \\
\hline & 13 & 52.3 & & Woven basket (Anjat) & 6-7 days & - & 30 & 100 & & \\
\hline & $($ Male $=4$ & & & Woven basket (Bakul) & 5-7 days & 30 & 35 & 100 & & \\
\hline$\circ$ & Female $=9$ ) & & $\tilde{5}$ & Winnowing basket & 1 day & - & 20 & - & & Own use, \\
\hline$\frac{\vec{\Xi}}{\stackrel{\vec{Z}}{\tilde{E}}}$ & & & 莺 & $B u b u$ & 3 days & 20 & - & 30 & $\begin{array}{l}\text { Own } \\
\text { use }\end{array}$ & $\begin{array}{l}\text { sale to } \\
\text { other } \\
\text { villagers }\end{array}$ \\
\hline & & & & Red rattan mat & 7 days & & $4 \mathrm{~m}=$ & & & \\
\hline & & & & Pandanus mat & 7 days & & $4 \mathrm{~m}=$ & & & \\
\hline & & & & Kedabang & 1 day & 20 & - & 30 & & \\
\hline & 13 & 34.5 & & Woven basket (Anjat) & 7 days & 30 & 50 & $80-100$ & & \\
\hline & $($ Male $=3$ & & & Woven basket (Bakul) & $2-5$ days & $25-30$ & $50-60$ & 70 & & \\
\hline & $\begin{array}{c}\text { Female }= \\
10)\end{array}$ & & $\approx$ & Winnowing basket & $\begin{array}{c}5 \\
\text { products/ } \\
\text { day }\end{array}$ & 15 & 20 & 25 & & Own use, \\
\hline 莣 & & & 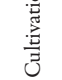 & $B u b u$ & 2 days & 15 & 30 & 100 & $\begin{array}{c}\text { Own } \\
\text { use }\end{array}$ & $\begin{array}{c}\text { sale to } \\
\text { other } \\
\text { villagers, }\end{array}$ \\
\hline & & & & Red rattan mat & 7 days & & $\mathrm{x} 8 \mathrm{~m}=$ & & & $\begin{array}{l}\text { sale to } \\
\text { market }\end{array}$ \\
\hline & & & & Pandanus mat & 7 days & & $1.8 \mathrm{~m}=$ & & & \\
\hline & & & & Kedabang & 1 day & 15 & $20-25$ & 30 & & \\
\hline
\end{tabular}

Note: The interview results suggest that the price of products is higher if the consumer orders from the producer, and lower if the producer offers them to consumers without orders. 


\section{B. Forest-related Activities of Forest Communities}

Results of this study suggested that the main livelihood of the households surveyed was cultivation - an activity with a definite tradition. Colchester et al. (2003) mentioned that forest communities have a number of distinctive characteristics regarding to their activities, such as rotational and shifting cultivation, hunting, fishing, and collecting forest products. Result of the study suggested that forest communities used to engage in mutual cooperation for cultivation, from land preparation to product harvesting. Households also used to help each other in clearing forest areas as new agricultural land. This custom prevailed for a long time since before the villagers settled in their current locations. Before settlement, they continually interacted with forests in relation to their livelihoods for hunting, fishing, and collecting forest products from their surroundings. They faced no difficulties in fulfilling their daily needs from forest resources, and could collect or find what they needed within a short time. After settlement, the forest communities still performed the same activities, but faced more limitations on access to forest materials, as the distance from their current villages to the resources is quite far compared to the pre-settlement period. Such communities therefore took longer time to collect NTFPs, and the amounts collected have also decreased. However, they still performed the same processes related to their activities regarding forests and NTFP utilization. One process that was very obviously related to NTFP utilization was collecting honey. The honey production peak was at the beginning of the fruit season when there were lots of flowers. Very few villagers had the skills required to climb trees for honey collection.

Some communities still utilized timber from secondary forests and NTFPs from primary forests. The timber was generally used for building houses, with any surplus being sold. While NTFPs were utilized mainly to fulfill daily needs, villagers also sold leftover materials. Since settling in their current locations, forest communities have continued to utilize NTFPs for handicraft making. Such groups usually made handicrafts to fulfill their own needs, and sold them to others if there was demand. Among the five villages-surveyed, only villagers in Seputuk who were running small-scale handicraft industry using NTFPs. Women made winnowing baskets cooperatively in bulk and sold their handicrafts in the market, while men made bubu and also sold them. It was found that skills related to NTFP utilization in the other four villages-surveyed were not yet optimal, although there was availability of natural resources. There were significant differences in NTFP utilization by villagers in Seputuk and those in the other four settlements. These discrepancies were affected by factors such as: 1) the community characteristics of each village, which result in different levels of skill and capability; 2 ) the easy access to and abundant availability of materials for making handicrafts in Seputuk village; and 3) the opportunity to make handicrafts as a trade item. Meanwhile, handicraft making was very scarce in Batu Lidung. 
The villagers in Batu Lidung were unaware of the potential of utilizing natural resources or NTFPs in economic support activities. This may have been caused by the following factors: 1) the location of the village near the district of capital made it more advanced than other villages inside the forest, which reduces villagers' forest dependency; and 2) although a plentiful supply of NTFPs was available, the variety of work opportunities means that villagers had little interest in utilizing the forest. These environmental differences between villagers in remote areas and those living near the district of capital affected their outlook. In other words, development affected ways of thinking.

\section{Activities Related to Handicraft Making in Seputuk Village}

In Seputuk village, $50 \%$ of females had the skills to make handicrafts. There was one small-scale industry group in Seputuk, whose members were all female. The group had eight members, and all were housewives with main livelihoods involving cultivation. However, this small-scale industry has increased their incomes by $50 \%$. In the village, most residents took the opportunity to utilize NTFPs for making handicrafts to run small-scale industry. Although they also engaged in cultivation for fruit trees and crops, the small-scale handicraft industry provided a significant boost to their incomes.

The working system of this group was based on mutual cooperation, with the eight members helping each other in making the winnowing baskets. For example, if member A helped member B to make ten baskets one day, on another day B would also help A to make ten units. This group was formed to facilitate the work involved in collecting materials and marketing. All activities related to this small-scale industry were performed collectively by the group's members, from work related to material collection in forests to market sales. The activity of making winnowing baskets in the group was performed in April, May, and June because the forest communities started preparing land for cultivation in July. Every year, from July until the following March, forest communities are busy with activities related to cultivation, such as preparing land in July, planting upland-rice in August, maintaining cultivation for the next several months, and finally harvesting in March.

In the small-scale industry group, each member was able to make five winnowing baskets a day, working from 9 a.m. to 12 p.m. and then from 1 p.m. to 4 p.m. Activities related to this manufacture include plaiting, binding with rope, and finishing. They worked only 1 - 2 days a week. The main material used for making winnowing baskets was bamboo, which was obtained from forests or sometimes from their own agricultural land. In each material collection session, one person collected the materials for one bamboo basket (equal to 15 sticks $\mathrm{x} 3$ internodes), and bamboo processing was then started. The bamboo was cut in half and the outer part only was removed, then it was thinned, rolled, and spread out in the sun to dry. The process of drying took about 5 days, after which they started to plait the bamboo to make winnowing baskets. 
The small-scale industry group had a single leader, who was responsible for organizing all activities related to the industry. The leader had to make sure that all members carry out all activities based on the agreements made, such as those involving mutual cooperation and working times. The central location for winnowing basket manufacture is the leader's house. The members of the group made a uniform (medium) size of winnowing baskets and sold them to the market at IDR 20,000 per unit (as of 2007). Small and large sizes could also be made, but since the medium size was the most common and sold well, the group decided to make one size only. The products were sold to the market once a batch of 50 units was completed.

\section{The Custom of NTFP Utilization: Why Are Females More Active?}

In NTFP utilization, women had more knowledge of forest products than men. Women in the villages surveyed, for example, knew and were able to choose high-quality rattan. Females in forest communities were major caretakers and users of forests. Besides had been more active in NTFP utilization than men, they were also the main gatherers of food and firewood, and seek out fruits, ferns, and nuts for their families. In addition, they used bark, roots, and herbs for medicinal purposes. Women's gathering activities were very important to household income and nutrition, and the products they collected represented important supplements for their families. Most of what they gathered was processed or sold for extra income. At the research site, women collected NTFPs for handicraft making - a key activity in providing income that enabled their families to live (FAO, 2008). Women also contributed to family life through many activities related to forests. They played a significant role in an agriculture system that incorporated trees and crops, and spent more time collecting NTFPs and firewood from forests. Research results suggested that women were active in NTFP utilization activities. Within forest communities, gender division in fulfilling living needs was a hereditary tradition. In terms of livelihoods, men assumed the responsibility for hard physical tasks such as timber cutting, while women took care of light work such as cooking and gathering NTFPs from forests. In fact, the female role of carrying rattan home from forests, which could involve a walk of 1 - 2 hours with the products on their shoulders could also be considered hard work.

There was also gender division in handicraft making based on product types (Table 3). Men usually had the skills for making bubu and anjat (woven basket), while women were usually adept at making mats, bakul (woven basket), winnowing basket, and kedabang. This difference in skills between males and females in making handicrafts was a hereditary tradition. However, there were occasions where men made bakul, winnowing basket, or kedabang, or females made bubu or anjat, although this had been found to be very rare. 


\section{E. Awareness in Forest Communities Regarding the Benefits of NTFP Utilization}

In the villages-surveyed, "fulfillment of life requirements" was ranked first among three categories of forest existence benefits for forest communities. "Both protection of ecosystem balance and fulfillment of life needs" were ranked second, and "no benefit" was ranked third. These life requirements included food from plants and animals, plantbased medicines, wood for housing, rattan for tying in hut construction, and fish from forest swamps. The animals which were usually hunted were monkeys, wild boars, deers, and monitor lizards. These results indicated that forest communities were more aware to the role of forests as a product provider than as an environment protector. Polling on the importance of education showed no effect on their points of view regarding to the roles of forests.

For such communities, forests played an important role in fulfilling their needs. Tens years ago, when forest communities were constantly shifting from one place to the other ones, they fully depended on forests for the necessities of daily life, including food, temporary housing, shelter, medicine, and recreation. Communities in or near forests usually practice shifting cultivation and utilize forest products, and most of them also have small gardens for permanent agriculture (Levang et al., 2005). At that time, these communities had not yet recognized currency, and did not need it at all in their lives; all their needs were met by forests, which provided them with real benefits. Forest communities had no restrictions on the use of forest products, and could cut timber easily whenever they needed to make small boats, build houses or collect firewood. They could find rattan readily when they needed it. They could also hunt animals easily and catch fish when they needed food. These conditions had gradually changed from 1945, when the Indonesian government started forcing forest communities to settle in one place in a policy designed to facilitate educational and health services for them. Since this settlement, children in such communities have entered education in formal schools.

Many years have passed since the forest communities settled in their current locations. However, although there was formal schooling for children, people in the five villages-surveyed still got low levels of education. This has affected ways of thinking, which in turn influences their ability to increase living standards. Ways of thinking also affected the ability of such communities to optimize natural resource utilization. Although a wider variety of jobs has become available for forest communities, most members of these groups at the research site were farmers. All of the 65 households surveyed were making handicrafts from NTFPs to fulfill their own needs, and some were selling these products to other villagers or to the market (Table 4). All 65 households realized that their skills were inherited from their ancestors, and that they should keep practicing them to prevent the gradual disappearance of such abilities. The other reasons why these residents made handicrafts were: 1) the materials required were provided by forests in the surrounding area; 2) there was a need for such handicrafts to fulfill their 
needs; 3) they received additional income when others buy these products from them; and 4) the additional income could support them when the cultivation failed.

\section{F. Awareness Regarding Opportunities for the Development of Small-Scale NTFPs Industry}

The establishment of forest concessionaire prompted a change in ways of thinking in forest communities, which started selling handicrafts to others or to the market as well as bartering them for other products based on agreement. The opinion poll question "Why do you make these handicrafts?" suggested the answers: 1) We have the skill to make them; 2) The materials are available around us and in the forest; 3) We need these products to fulfill our needs; and 4) If others want to buy our products, it will give us an additional income. In the five villages-surveyed, most forest communities were making handicrafts to fulfill their own needs and sell them to other villagers (Figure 2 a).

Among the survey targets, the forest communities in Seputuk village showed a higher level of development in utilizing NTFPs to make handicrafts. They formed and organized a group to run small-scale industry and sell the products to the market. Although their marketing system was simple (Figure 2b), but their desire to develop the business was great. The reasons of group members for running this small-scale industry were: 1) they could earn additional income; 2) market opportunities were large, as other communities had not yet established the same type of business; 3 ) they had the skills to make these handicrafts, and wanted to apply their skills in utilizing the materials found in abundance around them; and 4) they need a side job to secure their income when the cultivation failed.

A model for a more advanced marketing system is presented in Figure 2 c. The involvement of stakeholders in supporting communities for the utilization and management of NTFPs was very important. This study suggested that the 65 households surveyed who were active in NTFP utilization and handicraft making were ready to run these activities more seriously if there were stakeholders who were willing to assist them in managing their small-scale industry. This means that the achievement of a better life in forest communities depends not only on the residents themselves but also on the contribution of the stakeholders involved.

Among the five villages-surveyed, the forest communities in Punan Bengalun village were the slowest in starting to sell handicraft products because they were late in recognizing currency. The results of the field survey of 2008 suggested that until then they still bartered their handicraft products for other goods such as food. This forest community also had a lower level of education than the other four villages-surveyed because it was located in a more remote area. A road to the village was established by the local government, but it was impassable in rainy season. The route was unpaved and very steep, making it very slippery during and after rain. 
The research results suggested that a major challenge to the further development of NTFP utilization by forest communities was the limited availability of knowledge and information for such groups regarding market opportunities for the development of small-scale industry. Forest communities had the skills and capability to make handicrafts and run small-scale industry, but had no idea how to market the products.

In the five villages-surveyed, the major obstacles faced by forest communities were marketing problems and a lack of assistance and guidance. The residents there ran simple market systems that had scope for improvement in terms of increasing profits. However, this simple market setup stems from their own ideas, as they considered that the market system consists of two parts - producer and buyer - and they had already become familiar to this setup. At the research site, it was found that some villagers wanted to run smallscale industry related to natural resource and NTFP utilization seriously, but they were hindered by the difficulty of securing financial capital. Statistics describing the perception of the households surveyed toward NTFP utilization, handicraft making, and small-scale industry opportunities are presented in Table 5. One way to optimize NTFP utilization to provide business opportunities for forest communities was to allow the extension of such utilization on an optimum and efficient scale. Providing financial capital efficiently and effectively to communities wishing to run small-scale industry would also support them in the optimization of NTFP usage. The objective of these ideas was to find a way to optimize the use of NTFPs and to enhance life in forest communities. This goal can be realized through support provided by all the stakeholders involved (Table 6). 
(a)

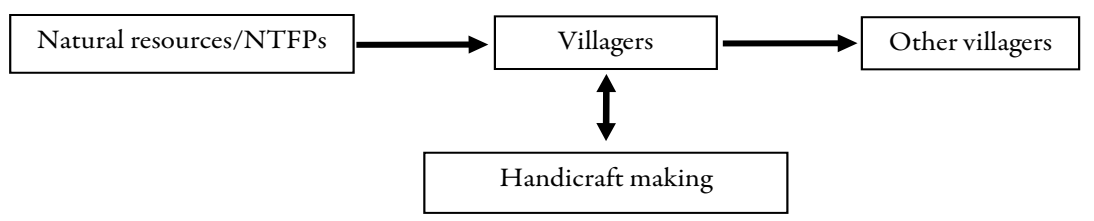

(b)

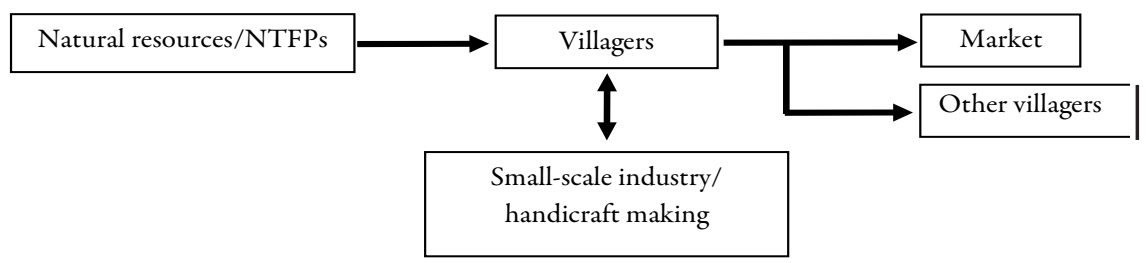

(c)

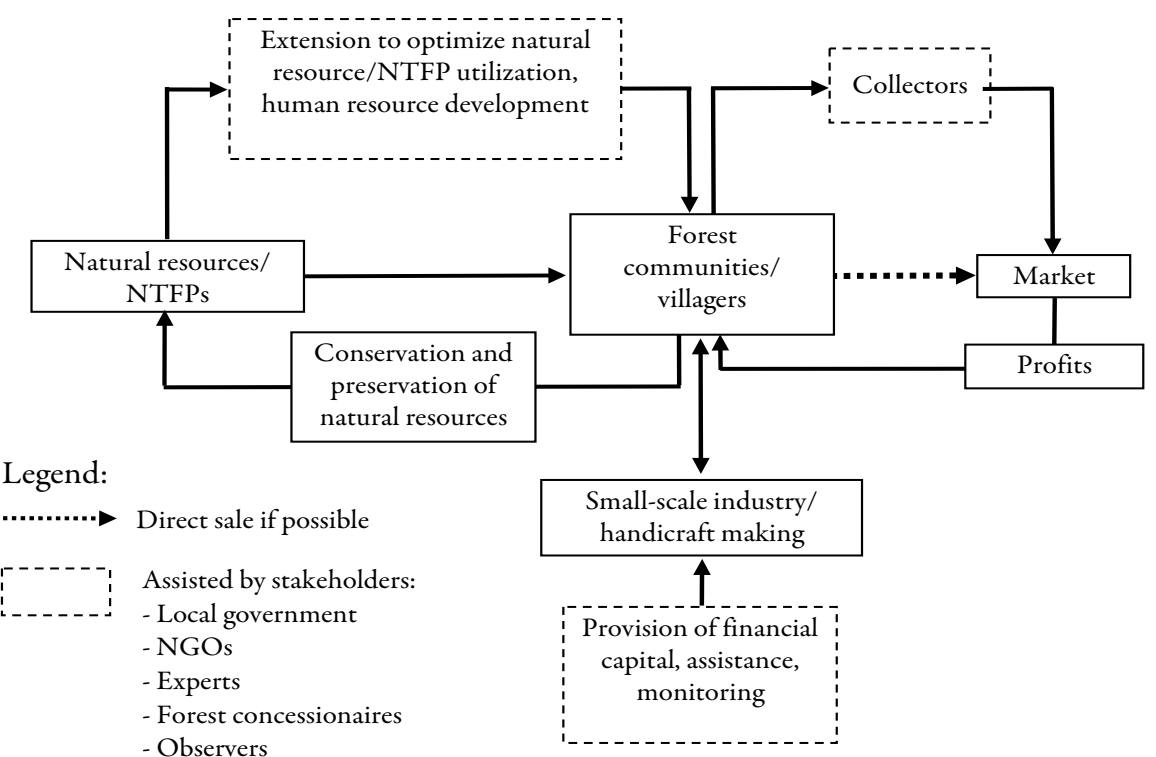

Figure 2. (a) Scheme of NTFP utilization and handicraft making in Mendupo, Batu Lidung, Sesua, and Punan Bengalun; (b) Scheme of NTFP utilization and handicraft making in Seputuk; (c) Recommended scheme for NTFP utilization and smallscale industry 
Table 5. Statistics describing household perceptions toward NTFP utilization, handicrafts, and small-scale industry opportunities (results of interview from 65 households in the five villages surveyed)

\begin{tabular}{|c|c|c|c|}
\hline Question & $\mathrm{n}$ & Mean & Std. dev. \\
\hline \multicolumn{4}{|l|}{ Where do you obtain materials for handicraft making (main source)? } \\
\hline$(0=$ forest, $1=$ agricultural land in secondary forest, $3=$ home garden $)$ & 65 & 0 & 0 \\
\hline \multicolumn{4}{|l|}{$\begin{array}{l}\text { Do you plant any of the following on your own agricultural land or in your home } \\
\text { garden? }\end{array}$} \\
\hline a. $\operatorname{Rattan}(\mathrm{no}=0$, yes $=1)$ & 65 & 0.48 & 0.50 \\
\hline b. Bamboo $($ no = 1, yes = 1) & 65 & 0.32 & 0.47 \\
\hline c. Silat trees $($ no $=0$, yes $=1)$ & 65 & 0 & 0 \\
\hline d. Pandan $($ no $=0$, yes $=1)$ & 65 & 0.35 & 0.48 \\
\hline \multicolumn{4}{|l|}{ How do you rate access to NTFPs in forest areas } \\
\hline \multicolumn{4}{|l|}{ in 2008 compared to 18 years ago (1990)? } \\
\hline$($ easier $=0$, the same $=1$, more difficult $=2)$ & 65 & 1.51 & 0.50 \\
\hline \multicolumn{4}{|l|}{ What is your main purpose in making handicrafts? } \\
\hline (own use $=0$, sale to other villagers $=1$, sale to market $=2$ ) & 65 & 1 & 0.79 \\
\hline \multicolumn{4}{|l|}{ Do you believe you can improve your economic standing by making handicrafts? } \\
\hline$($ no $=0$, don't know $=1$, yes $=2)$ & 65 & 1.74 & 0.51 \\
\hline \multicolumn{4}{|l|}{ a) Do you want to run small-scale industry related to handicrafts? (for } \\
\hline \multicolumn{4}{|l|}{ households who have not started small-scale industry yet) / b) Do you } \\
\hline \multicolumn{4}{|l|}{ want to develop your small-scale industry (for households who have } \\
\hline \multicolumn{4}{|l|}{ started small-scale industry) } \\
\hline$($ no $=0$, don't know $=1$, yes $=2)$ & 65 & 1.57 & 0.66 \\
\hline
\end{tabular}


Table 6. Recommended assistance programs to be implemented by stakeholders to optimize NTFP utilization

\begin{tabular}{|c|c|c|c|}
\hline No. & $\begin{array}{l}\text { Recommended } \\
\text { support activity }\end{array}$ & Purpose & Stakeholders involved \\
\hline 1 & $\begin{array}{l}\text { Provision of guidance on } \\
\text { the potential of natural resources }\end{array}$ & $\begin{array}{l}\text { To increase awareness of utilizing } \\
\text { natural resources toward the } \\
\text { enhancement of community living } \\
\text { standards }\end{array}$ & $\begin{array}{l}\text { Local government, } \\
\text { forest concessionaires }\end{array}$ \\
\hline 2 & $\begin{array}{l}\text { Provision of financial capital for } \\
\text { small-scale industry }\end{array}$ & $\begin{array}{l}\text { To offer financial support for } \\
\text { communities toward optimizing the } \\
\text { capacity for small-scale industry }\end{array}$ & $\begin{array}{l}\text { Local government, } \\
\text { forest concessionaires }\end{array}$ \\
\hline 3 & Infrastructure development & $\begin{array}{l}\text { To support the infrastructure } \\
\text { needed by communities to increase } \\
\text { living standards }\end{array}$ & $\begin{array}{l}\text { Local government, } \\
\text { forest concessionaires }\end{array}$ \\
\hline 4 & Educational improvement & To broaden knowledge & $\begin{array}{l}\text { Local government, } \\
\text { forest concessionaires } \\
\text { (in cooperation with } \\
\text { experts, NGOs, and } \\
\text { observers) }\end{array}$ \\
\hline
\end{tabular}

\section{CONCLUSIONS}

Most of the forest communities in Batu Lidung, Punan Bengalun, Sesua, Mendupo, and Seputuk are still depending on NTFPs in supporting of their livelihood, even though now days to collect those sources is not easy anymore due to decreasing of forest lands.

Some communities in the five surveyed-villages were aware regarding on the benefits of NTFPs utilization for industry. Activities related to handicraft making by forest communities have prevailed for many generations, and started selling their products to others since recognizing currency - even more so since the establishment of the forest concessionaire in the area.

Forest communities in Seputuk village have started running small-scale industry involving handicraft making using NTFPs since 2000. This small-scale industry group was established under their own initiative, since they recognized market opportunities. Awareness related to NTFP utilization for small-scale industry was due to a number of factors, mainly the location of NTFPs are become remote and there is a tendency that people close to the district capital have a limited desire to utilize NTFPs, and therefore they mostly prefer to get other job, even though, small-scale NTFP-based industry has a potential to increase the number of local employment opportunities and provides additional income. 


\section{ACKNOWLEDGMENT}

The author gratefully acknowledges the financial assistance provided by the International Tropical Timber Organization (ITTO), and also thanks PT. Intracawood Manufacturing for its cooperation and assistance during the field survey. The author thanks Dr. Ir. Taulana Sukandi, M.Sc and Dr. Ir. Kade Sidiyasa for their helpful suggestion on this paper.

\section{REFERENCES}

Ali, T., M. Ahmad, B. Shahbaz, and A.Q. Suleri. 2007. Impact of participatory forest management on financial assets of rural communities in Northwest Pakistan. Ecological Economics, doi:10.1016/j.ecolecon.2006.12.017.

BPS (Badan Pusat Statistik). 2006. Berita Resmi Statistik No 47/IX/1 September 2006 (in Indonesian). Jakarta.

Colchester, M., M. Sirait, and B. Wijardjo. 2003. The applications of FSC Principles No. $2 \& 3$ in Indonesia: Obstacles \& possibilities. WALHI, AMAN, and the Rainforest Foundation. Bogor, Indonesia.

FAO (Food and Agriculture Organization). 1997. Asia-Pacific forestry sector outlook study: Technology scenarios in the Asia-Pacific Forestry sector. Working Paper No. APFSOS/WP/25.

FAO (Food and Agriculture Organization). 2008. Gender and non-timber forest products: Promoting food security and economic empowerment. International Fund for Agricultural Development. Rome, Italy.

Indonesian Forestry Department. 2007. Data on forest concession holders in Indonesia by the Indonesian Forestry Department (not published).

Komarudin H., Y.L. Siagian, and N.P. Oka. 2007. Linking collective action to nontimber forest product market for improved local livelihoods: Challenges and opportunities. CAPRI Working Paper No. 73, December 2007.

Levang, P., E. Dounias, and S. Sitorus. 2005. Out of the forest, out of poverty? Forests, Trees and Livelihoods Journal 15: 211-236.

Limberg, G., R. Iwan, E. Wollenberg, and M. Moeliono. 2005. Opportunities and constraints to community forestry: Experience from Malinau. Governance Brief. CIFOR. Bogor, Indonesia.

Malik, J. and E.S. Sumadiwangsa. no year. Research, development and utilization strategy of non timber forest product: Indonesia case. Available at http://www.fao.org/ DOCREP/ARTICLE/WFC/XII/0446-A2.HTM (accessed on 1st July 2009). 
Mittermeier, R.A. and I.A. Bowles. 1993. The GEF and biodiversity conservation: Lessons to date and recommendations for future actions. Conservation International Policy Papers I, US.

Palmer, C. 2004. The role of collective action in determining the benefits from IPPK logging concessions: A case study from Sekatak, East Kalimantan. Center for International Forestry Research, Bogor.

Pierce, A.R. 1999. The challenges of certifying non-timber forest products. Journal of Forestry 97 (2).

Quang, D.V. and T.N. Anh. 2006. Commercial collection of NTFPs and households living in or near the forests: Case study in Que, Con Cuong and Ma, Tuong Duong, Nghe An, Vietnam. Ecological economics 60: 65-74.

Suwarno, A. and B. Campbell. 2005. Modeling the dynamics of landscapes and livelihoods in Malinau District, Indonesia. Proceedings of MODSIM 2005 International Congress on Modeling and Simulation Society of Australia and New Zealand, Melbourne, 12-15 December 2005.

Tewari, D.D. and J.Y. Campbell. 1995. Developing and sustaining non-timber forest products: some policy issues and concerns with special reference to India. J. Sust. For., 3(1): 53-79.

Yasmi, Y. 2003. Understanding conflict in the co-management of forest: the case of Bulungan Research Forest. International Forestry Review 5 (1). 